\title{
INDIVIDUAL MODELS FOR DIAMETER AND HEIGHT PROJECTION WITH CONTRIBUTION OF COMPETITION INDEX IN Pinus taeda L. STANDS
}

\author{
Rodrigo Otávio Veiga de Miranda ${ }^{1}{ }^{*}$, Afonso Figueiredo Filho ${ }^{2}$, Ângelo Augusto Ebling ${ }^{3}$, Hassan Camil David ${ }^{4}$ \\ Mailson Roik ${ }^{5}$
1* Federal University of Uberlândia, Institute of Agrarian Sciences, Monte Carmelo, Minas Gerais, Brazil - rovmiranda@gmail.com ${ }^{2}$ Midwest State University, Department of Forest Engineering, Irati, Paraná, Brazil - afonso@ unicentro.br
${ }^{3}$ Federal Rural University of Amazônia, Department of Forest Engineering, Parauapebas, Pará, Brazil - angelo.ebling@ufra.edu.br
${ }^{4}$ Brazilian Forest Service. Ministry of Agriculture, Livestock and Supply, Brasília, DF, Brazil - hassan.david@ florestal.gov.br ${ }^{5}$ STCP Project Engineering, Paraná, Brazil - mailsonroik@ hotmail.com \\ Received for publication: 27/02/2021 - Accepted for publication: 26/04/2021
}

\begin{abstract}
Resumo
Modelos individuais para projeção do diâmetro e altura com contribuição do índice de competição em povoamentos de Pinus taeda L. O objetivo deste trabalho foi avaliar e propor modelos para projeção do diâmetro à altura do peito e altura total para árvores individuais de pinus e a contribuição de índices de competição nesses modelos. Os dados foram provenientes de 1.056 unidades amostrais permanentes de povoamentos não desbastados de Pinus taeda L. localizados na região de Telêmaco Borba, estado do Paraná, Brasil, com idades de 3,4 a 19,5 anos. Para projetar o diâmetro e altura total das árvores, modelos lineares foram testados, em função da própria variável na idade atual, da idade de projeção no futuro, da área basal e do índice de sítio, assim como transformações dessas variáveis. A correlação de Spearman foi obtida entre índices de competição e variáveis dendrométricas e do povoamento, sendo selecionados os índices GH (Glover e Hool), LO (Lorimer) e ST (Stage). Esses índices foram avaliados como variáveis independentes nos modelos, cujas contribuições foram verificadas por meio do teste " $F_{\mathrm{ci}}$ " de contribuição incremental. Os modelos foram avaliados pelo coeficiente de determinação ajustado, erro padrão da estimativa e boxplots dos resíduos. Os modelos forneceram projeções precisas e livres de tendência. Os índices de competição contribuíram estatisticamente para a projeção do diâmetro e da altura total conforme indicado pelo teste " $F_{c i}$ ", aumentando a precisão dos valores projetados para a maioria dos modelos testados. Os índices com maiores contribuições na projeção do diâmetro e altura total de Pinus taeda foram os de Glover e Hool (GH) e o de Lorimer (LO), respectivamente.

Palavras-chave: modelos de projeção, índices de competição, contribuição marginal.
\end{abstract}

Abstract
The aim if this work was to assess and propose projection models for diameter at breast height and total height
of individual pine trees and the contribution of competition indexes in these models. Data was obtained from
1056 permanent sampling units of non-thinned Pinus taeda L. stands located in the Telêmaco Borba region,
Paraná, Brazil, with ages between 3.4 and 19.5 years. In order to project the diameter and total height of the
trees, linear models were tested according to the variable in the current age, the projection age in the future, the
basal area, and the site index, as well as their transformations. The Spearman correlation was obtained between
competition indexes and dendrometric and stand variables, with the GH (Glover and Hool), LO (Lorimer) and
ST (Stage) indexes being selected. These indexes were assessed as independent variables in the models, whose
contributions were verified through the "F $F_{\text {ci" test on the incremental contribution. The models were assessed }}$
through the adjusted coefficient of determination, standard error of the estimate, and boxplots of residuals. The
models provided precise and bias-free projections. The competition indexes statistically contributed to diameter
and total height projection according to the "F $F_{c i}$ " test, increasing the precision of projected values for the
majority of models tested. The indexes with major contributions to individual tree modelling for diameter and
total height projection of Pinus taeda were Glover and Hool (GH) and Lorimer (LO), respectively.
Keywords: projection models, competition indexes, marginal contribution.

\section{INTRODUCTION}

Growth and production models for individual trees have great flexibility and characterize in a precise manner the growth of stands under several conditions with detailed results (WEISKITTEL et al., 2011) such as stand structure and dynamics. The understanding of growth (or increment) of individual trees is important to know the dynamics and productivity of forest biomass, as well as plan the wood supply and subsidize forest management (CARRIJO et al., 2019).

In the simulation of growth by individual tree modelling, the information about diameter at breast height and total height are usually used due to their strong correlation with total volume of trees (WEISKITTEL et al., 2011). This modelling can be subdivided into distance-dependent, independent, and semi-dependent models (CONTRERAS et al., 2011). 
Distance-independent models typically consist of three basic components: a diameter growth equation, a height growth equation, and a mortality component (BURKHART; TOMÉ, 2012). In these models, growth by tree is simulated according to their attributes, basal area, crown ratio, site quality, and a measurement that expresses tree competition, such as a competition index (BURKHART; TOMÉ, 2012).

Competition indexes are a way of analytically representing the competitive status of a tree in the forest stand, being calculated by mathematical formulations, able to consider variables of the competing trees and the stand, and distance measures.

The consideration or not of a distance measure between the trees defines the dependent and independent indexes of the distance. There are still semi-independent distance indexes, representing the most recent class of these competition indexes. The most used competition indexes are described in Costa et al. (2020). These indexes represent an important tool for forest management (PEDERSEN et al., 2013).

Two conceptual approaches have been useful to estimate individual tree growth. The first, from the direct growth estimate using regression analysis; and the second, in an indirect and robust way, by using a modifier function of potential growth (WEISKITTEL et al., 2011). Martins et al. (2011) reported that there is no confirmation of the advantages of modifier functions in relation to regression equations.

Canopy modifications can be modelled according to diameter and transversal area, as well as their respective increments. In this sense, there is debate regarding the preference to model increment in transversal area or in diameter, however, there is no superiority of a model over another (WEISKITTEL et al., 2011).

Studies in Brazil have been developed to assess individual growth of several species, being the major part performed with the use of increment modelling instead of production modelling. Among those who modelled increment we have the works of Chassot et al., (2011) for araucaria trees (Araucaria angustifolia (Bertol.) Kuntze); Martins et al. (2011) and Carrijo et al. (2019) for eucalyptus clones; Santos et al. (2015) for imbuia (Ocotea porosa (Nees \& Mart.) Barroso); Cunha et al. (2016) for commercial Amazonian species; Castro et al. (2014) and Silveira et al. (2015) for species of the Semideciduous Seasonal Forest; Orellana et al. (2016) for species of the Mixed Ombrophilous Forest in south Brazil.

Although the genus Pinus has great importance in the Brazilian forestry sector, especially in the south of Brazil, individual tree models for this genus are scarce, mainly due to the greater use of whole-stands and diameter classes models. Therefore, the aim of this work was to assess and propose individual projection models for diameter and total height, with competition index as an independent variable, under the hypothesis that these competition indexes significantly contribute with projection models for diameter and height in Pinus taeda stands.

\section{MATERIAL AND METHODS}

The area of this study has a slightly undulated relief and average altitude $743 \mathrm{~m}$ above sea level. According to Köppen-Geiger classification, the local climate is Cfa, mean annual temperature is $19.3{ }^{\circ} \mathrm{C}$, and average annual rainfall is 1,437 mm (CLIMATE-DATA.ORG, 2021).

Data were obtained from 1,056 permanent sampling units randomly distributed in non-thinned commercial plantings of Pinus taeda L., with ages varying between 3.4 and 19.5 years, spacing of $2.5 \times 2.5 \mathrm{~m}$, located in Telêmaco Borba, in the Campos Gerais region, Paraná state, Brazil. The approximate sampling intensity was one sampling unit by hectare.

Each sampling unit was determined by the count of 10 planting lines and 10 plants per line. In each line, the diameter at breast height of all trees, the total height $(\mathrm{h})$ of the ten first trees, and the total height of the dominant trees were measured. The total height $(\mathrm{h})$ of the remaining trees of the sampling units was estimated by the following generic hypsometric equation:

$$
h=e^{0.72145+0.02395 S-5.90105 d^{-1}+0.72669 \ln (I)}(R M S R \%=6.7 \%)
$$

Where: $\mathrm{S}=$ site index $(\mathrm{m}) ; \mathrm{d}=$ diameter at $1.3 \mathrm{~m}$ above ground $(\mathrm{cm}) ; \mathrm{I}=$ age (years), RMSR\% = root mean square residual.

The site classes were established by the guide curve method, in which the Chapman-Richards model and the index age of 18 years were used, whose resulting equation was:

$$
h_{\text {dom }}=41.224399\left(1-e^{-0.061832 I}\right)^{1.156161}\left(\mathrm{~S}_{\mathrm{yx}}=9.5 \%\right)
$$

Where: $\mathrm{h}_{\mathrm{dom}}=$ dominant height $(\mathrm{m}) ; \mathrm{I}=$ age (years); $\mathrm{S}_{\mathrm{yx}}=$ standard error of the estimate. 
Three site classes were established: class I $\left(28.0<\mathrm{h}_{\mathrm{dom}} \leq 33.0 \mathrm{~m}\right)$; class II $\left(23.0<\mathrm{h}_{\mathrm{dom}} \leq 28.0 \mathrm{~m}\right)$; and class III $\left(18.0 \leq \mathrm{h}_{\mathrm{dom}} \leq 23.0 \mathrm{~m}\right)$, representing the classes of high, medium, and low productivity, respectively.

The descriptive statistics of the sample for each variable used are in Table 1, to fit as well as test the projection models of diameter and total height. To testing of projection models 300 sampling units were used. Trees with height shorter than $4 \mathrm{~m}$ were disregarded due to the wide variation. The discrepant values (outliers) related to the projection of heights were also removed from the dataset, which focused on initial ages.

Table 1. Range of variables used in the adjustment and testing of projection models of diameter and total height for a Pinus taeda stand located in the Telêmaco Borba region, Paraná state, Brazil

Tabela 1. Amplitude das variáveis utilizadas no ajuste e teste dos modelos de projeção do diâmetro e altura total para povoamento de Pinus taeda localizado na região de Telêmaco Borba, Paraná, Brasil

\begin{tabular}{|c|c|c|c|c|c|c|c|c|c|c|}
\hline \multirow{2}{*}{ Variable } & \multicolumn{5}{|c|}{ Fitting } & \multicolumn{5}{|c|}{ Test } \\
\hline & Min & Med & Max & CV (\%) & NP & Min & Med & Max & $\mathrm{CV}(\%)$ & NP \\
\hline $\mathrm{d}(\mathrm{cm})$ & 3.8 & 17.6 & 53.8 & 29.8 & 96,037 & 4.1 & 17.8 & 39.8 & 29.3 & 29,653 \\
\hline $\mathrm{h}(\mathrm{m})$ & 4.0 & 12.5 & 30.2 & 41.3 & 85,060 & 4.8 & 12.8 & 28.9 & 39.5 & 29,177 \\
\hline I (years) & 3.4 & 8.0 & 19.5 & 44.6 & NPVM & 3.6 & 8.4 & 19.2 & 43.6 & NPVM \\
\hline $\mathrm{G}\left(\mathrm{m}^{2} \mathrm{ha}^{-1}\right)$ & 5.1 & 35.8 & 75.2 & 37.8 & NPVM & 6.8 & 37.8 & 73.2 & 37.6 & NPVM \\
\hline $\mathrm{S}(\mathrm{m})$ & 18.7 & 26.6 & 36.7 & 10.0 & NPVM & 17.5 & 26.4 & 34.9 & 10.0 & NPVM \\
\hline
\end{tabular}

Where: $\mathrm{d}=$ diameter at breast height; $\mathrm{h}=$ total height; $\mathrm{I}=$ age; $\mathrm{G}=$ basal area; $\mathrm{S}=$ site index; Min, Med and Max = minimum, medium and maximum values; $\mathrm{NP}=$ number of paired data; NPVM = number of paired data of the modelled variable (diameter or total height).

According to a preliminary analysis through the correlation between dendrometric and stand variables and distance-independent competition indexes, higher correlation values were observed for diameter and height, compared to their respective increments. Thus, projection models of diameter and height were tested and assessed.

The projection models of diameter and total height were based on a model whose production, in an age of interest $\left(\mathrm{Y}_{2}\right)$, was estimated according to the same variable in a current age $\left(\mathrm{Y}_{1}\right)$, the interest age, the site index of the area and basal area of the stand, resulting in a multiple linear model (model 1) (Table 2).

Competition indexes were also assessed as an independent variable in the projection models of diameter and total height. Other four models (models 2 to 5) were tested, whose dependent and independent variables were the same previously described, however changed by some sort of transformation, selected through Spearman correlation $(\alpha \leq 0.05)$, in order to not repeat the variable in the model (CHASSOT et al., 2011).

Table 2. Projection models of diameter and total height for a Pinus taeda stand located in the Telêmaco Borba region, Paraná state, Brazil

Tabela 2. Modelos de projeção do diâmetro e altura total para povoamento de Pinus taeda localizado na região de Telêmaco Borba, Paraná, Brasil

\begin{tabular}{cc}
\hline Model $\mathbf{N}^{\mathbf{0}}$ & Model \\
\hline 1 & $Y_{2}=\beta_{0}+\beta_{1} Y_{1}+\beta_{2} I_{2}+\beta_{3} S+\beta_{4} G+\left[\beta_{5} I C_{i}\right]+\varepsilon_{i}$ \\
2 & $Y_{2}=\beta_{0}+\beta_{1} Y_{1}^{2}+\beta_{2}\left(I_{2} S\right)^{-1}+\beta_{3} \ln (G)+\left[\beta_{4} I C_{i}\right]+\varepsilon_{i}$ \\
3 & $\ln \left(Y_{2}\right)=\beta_{0}+\beta_{1}\left(Y_{1} S\right)^{-1}+\beta_{2} \ln \left(G I_{2}\right)+\left[\beta_{3} I C_{i}\right]+\varepsilon_{i}$ \\
4 & $\ln \left(Y_{2}\right)=\beta_{0}+\beta_{1} \ln \left(Y_{1}\right)+\beta_{2} \ln \left(I_{2} S\right)^{-1}+\beta_{3} \ln (G)+\left[\beta_{4} I C_{i}\right]+\varepsilon_{i}$ \\
5 & $\ln \left(Y_{2}\right)=\beta_{0}+\beta_{1} \ln \left(Y_{1} S\right)^{-1}+\beta_{2} \ln \left(G I_{2}\right)+\left[\beta_{3} \ln \left(I C_{i}+1\right)\right]+\varepsilon_{i}$
\end{tabular}

Where: $\mathrm{Y}_{1}$ and $\mathrm{Y}_{2}=$ variable of interest (diameter and height) in the current and projected age, respectively; $\mathrm{I}_{2}=$ projection age (years); $\mathrm{S}=$ site index $(\mathrm{m}) ; \mathrm{G}=$ basal area $\left(\mathrm{m}^{2} \mathrm{ha}^{-1}\right)$ in the current age; $\mathrm{IC}_{\mathrm{i}}=$ competition index; $\varepsilon_{\mathrm{i}}=$ random error of the model; ln $=\mathrm{Napier}$ 's logarithm.

Several competition indexes were tested, and the most correlated with diameter were GH (GLOVER; HOOL, 1979) and LO (LORIMER, 1983), and the most correlated with total height were LO and ST (STAGE, 
1973 - BAL), thus being included in the models to project diameter and height. These indices are presented in Costa et al. (2020) e Schons et al. (2020). The indexes were calculated with the expressions to follow.

$$
S T=\sum_{j=1}^{n} g_{i} \quad G H=\left(d_{i} \bar{d}^{-1}\right)^{2} \quad L O=\sum_{j=1}^{n} d_{j} d_{i}^{-1}
$$

Where $\mathrm{d}_{\mathrm{i}}$ is the diameter at breast height of the object tree $(\mathrm{cm})$; $\mathrm{d}_{\mathrm{j}}$ the diameter at breast height of the competitor trees $(\mathrm{cm}) ; \quad \bar{d}=$ the arithmetic mean value of the diameters at breast height of trees in the sampling unit $(\mathrm{cm})$; $g_{i}=$ transversal area of trees larger than the object tree $\left(\mathrm{m}^{2}\right)$.

These competition indexes were tested as independent variables in the models, being selected the one with the highest statistical contribution to the projections. In order to verify the statistical contribution of the competition index to the models, the marginal or increment contribution was calculated based on the analysis of variance, through the " $\mathrm{F}_{\mathrm{ci}}$ " test, according to the expression to follow.

$$
F_{c i}=\left[\left(S Q E_{\text {new }}-S Q E_{\text {old }}\right) / n_{i}\right]\left[\left(S Q R_{\text {new }}\right) /\left(n-p_{\text {new }}\right)\right]^{-1}
$$

Where $\mathrm{F}_{\mathrm{ci}}$ is the test of increment contribution; $\mathrm{SQE}_{\mathrm{old}}$ is the sum of regression squares of the old model, that is, not including the new independent variable; $\mathrm{SQE}_{\text {new }}$ is the sum of the regression squares of the new model, including the new independent variable; $\mathrm{SQR}_{\text {new }}$ is the sum of the squares of model residuals with the new independent variable; $\mathrm{n}_{\mathrm{i}}$ is the number of new variables included in the model; $\mathrm{n}$ is the number of observations; and $\mathrm{p}_{\text {new }}$ is the number of parameters of the model including the new independent variable.

In practical terms, this statistical test is indicated when there are doubts regarding the statistical viability of adding an independent variable when there are other independent variables in the model (GUJARATI; PORTER, 2011). The result of the " $F_{\mathrm{ci}}$ " test was compared with the tabled value of Fisher-Snedecor " $F$ ", corresponding to the number of degrees of freedom of numerator and denominator of the ratio of the sum of squares, considering the 5\% significance. Models were fitted with and without the competition indexes. This test is similar to the partial F-test used by Tomé and Burkhart (1989) and Martins et al. (2011).

The fits were assessed with the adjusted coefficient of determination $\left(\mathrm{R}^{2}{ }_{\text {aj }}\right)$, the standard error of the estimate percentage ( $\left.\mathrm{S}_{\mathrm{yx}} \%\right)$, both calculated for the variable of interest (Machado et al. 2015), and the residual graphic analysis with boxplots.

To analyse the precision of the models applied in the database selected for testing, the root mean square residual (RMSR) was applied, according to the expression to follow.

$$
R M S R \%=100 \times\left[\sum_{i=1}^{n}\left(Y_{i}-\hat{Y}_{i}\right)^{2} / n\right]^{1 / 2} / \bar{Y}
$$

Where RMSR was calculated in percentage, being "n" the number of paired data, $Y_{i}$ and $\hat{Y}_{i}$ the observed and estimated values, respectively. For the models which the dependent variable had a logarithmic transformation (Ln), the projected variable was multiplied by the correction factor of Meyer logarithmic discrepancy (FM) before the statistical calculations, according to the methodology applied by Sanquetta et al. (2017).

\section{RESULTS}

\section{Fitting of the diameter projection models}

The five models were fitted to data and assessed. All coefficients were significant at $5 \%$ significance level (Table 3). The fits in which competition indexes in the model were disregarded performed less than those with the inclusion of these indexes, in all situations, with emphasis on models 3 and 5 and the use of index GH as an independent variable. According to the " $\mathrm{F}_{\mathrm{ci}}$ " test, competition indexes contributed statistically to the projected values of diameter, except for the index LO for model 4. The t-test indicated that the coefficients associated with competition indexes were significant in the models. Based on the results found, model 1, which used the competition index $\mathrm{GH}$, provided the best statistical results.

Table 3. Coefficients and statistics of the tested projection models for diameter in a Pinus taeda stand in the Telêmaco Borba region, Paraná state, Brazil 
Tabela 3. Coeficientes e estatísticas dos modelos testados para projeção do diâmetro, para povoamento de Pinus taeda localizado na região de Telêmaco Borba, Paraná, Brasil

\begin{tabular}{|c|c|c|c|c|c|c|c|c|c|c|}
\hline $\mathbf{N}^{0}$. & Model & $\boldsymbol{\beta}_{0}$ & $\beta_{1}$ & $\boldsymbol{\beta}_{2}$ & $\boldsymbol{\beta}_{3}$ & $\boldsymbol{\beta}_{4}$ & $\beta_{5}$ & $\mathbf{R}^{2}$ aj & $\mathrm{S}_{\mathrm{yx}} \%$ & $\mathbf{F}_{\text {ci }}$ \\
\hline \multirow{3}{*}{1} & W/out IC & $-0.4136^{*}$ & $1.1098 *$ & $0.0395 *$ & $0.1200 *$ & $-0.0927 *$ & - & 0.95 & 5.76 & - \\
\hline & $\mathrm{GH}$ & $-1.0818 *$ & 0.9299* & $0.0967 *$ & $0.1225^{*}$ & $-0.0578^{*}$ & $1.7812 *$ & 0.96 & 5.59 & $5,904.9 *$ \\
\hline & LO & $0.7052 *$ & $1.0640^{*}$ & $0.0380^{*}$ & 0.1197* & $-0.0804 *$ & $-0.0080^{*}$ & 0.96 & 5.73 & $694.1 *$ \\
\hline \multirow{3}{*}{2} & W/out IC & $18.3960 *$ & $0.0262 *$ & $-160.068 *$ & $-2.0377 *$ & - & - & 0.90 & 8.59 & - \\
\hline & $\mathrm{GH}$ & $10.1976 *$ & $0.0142 *$ & $-612.996^{*}$ & $0.4721 *$ & $5.1891 *$ & - & 0.94 & 6.67 & $62,946.0 *$ \\
\hline & LO & $19.2756^{*}$ & $0.0184^{*}$ & $-221.303^{*}$ & $0.2108^{*}$ & $-0.0639^{*}$ & - & 0.94 & 6.69 & $62,330.0 *$ \\
\hline \multirow{3}{*}{3} & W/out IC & $3.55803 *$ & $-293.913^{*}$ & $0.0162 *$ & - & - & - & 0.81 & 11.81 & - \\
\hline & $\mathrm{GH}$ & $2.70403 *$ & $-155.798 *$ & $0.1060 *$ & $0.3309 *$ & - & - & 0.92 & 7.59 & $365,285.4 *$ \\
\hline & $\mathrm{LO}$ & $2.34812 *$ & $-129.539 *$ & $0.1108 *$ & $-0.0058 *$ & - & - & 0.90 & 8.51 & $112,602.0^{*}$ \\
\hline \multirow{3}{*}{4} & W/out IC & $3.14187^{*}$ & $1.0230 *$ & $-0.0714^{*}$ & $-0.2180 *$ & - & - & 0.95 & 5.94 & - \\
\hline & $\mathrm{GH}$ & $0.41214 *$ & $0.8370^{*}$ & $-0.1022 *$ & $-0.1449 *$ & $0.2245 *$ & - & 0.95 & 5.79 & $49,674.9^{*}$ \\
\hline & LO & $0.36667 *$ & $1.1527 *$ & $-0.0742 *$ & $-0.2855^{*}$ & $0.1272 *$ & - & 0.95 & 5.90 & $-46.4^{\mathrm{ns}}$ \\
\hline \multirow{3}{*}{5} & W/out IC & $0.35458^{*}$ & $-293.913^{*}$ & $0.0162 *$ & - & - & - & 0.81 & 11.81 & - \\
\hline & GH & $-0.3064 *$ & $-121.254^{*}$ & $0.1293 *$ & $0.7947 *$ & - & - & 0.94 & 6.82 & $439,168.6^{*}$ \\
\hline & LO & $3.55803^{*}$ & $-147.001 *$ & $0.0989 *$ & $-0.5631 *$ & - & - & 0.91 & 8.11 & $214,720.3^{*}$ \\
\hline
\end{tabular}

Where: W/out IC = fitted model without the competition index; $\mathrm{GH}=$ competition index (Glover and Hool); LO = competition index (Lorimer); $\mathrm{R}^{2}{ }_{\mathrm{aj}}=$ adjusted coefficient of determination; $\mathrm{S}_{\mathrm{yx}} \%=$ standard error of the estimate percentage; $\mathrm{F}_{\mathrm{ci}}=\mathrm{F}$-test for marginal or increment contribution; $\beta_{\mathrm{i}}=$ estimated coefficients; $*$ significant at $5 \% ;{ }^{\text {ns }}=$ non-significant at $5 \%$.

The boxplots of residuals for model 1 of diameter projection using the competition index GH is shown in Figure 1. These boxplots of residuals indicated a slight tendency to overestimation of diameters in the initial classes.

On the other hand, from the diameter class of $10 \mathrm{~cm}$, a large part of residuals was around "zero", biasfree, with few extreme values (outliers). With the advance of diameter classes, the precision of projected values increased, since there was a reduction in the range of variation. By also considering the extreme values, variation oscillated mostly $\pm 30 \%$.

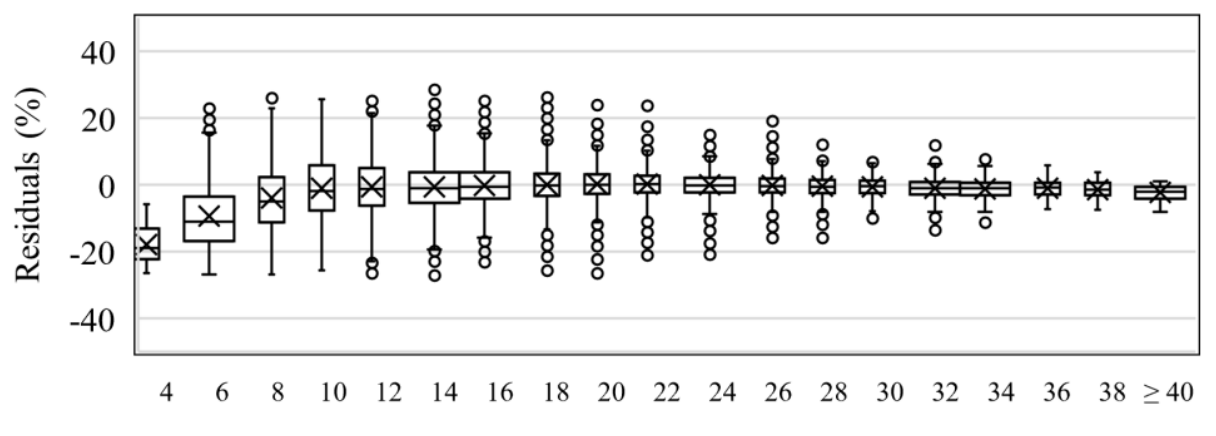

Center of the current diameter class $(\mathrm{cm})$

Figure 1. Boxplots of residuals by current diameter class for model 1 with competition index GH for diameter projection in a Pinus taeda stand in the Telêmaco Borba region, Paraná state, Brazil.

Figura 1. Boxplots dos resíduos por classe de diâmetro atual para o modelo 1 com índice de competição GH para projeção do diâmetro em povoamento de Pinus taeda localizado na região de Telêmaco Borba, Paraná, Brasil.

\section{Fitting of the height projection models}

The statistics of fits assessment and the estimated coefficients of the models for total height projection as well as diameter projection indicated all coefficients significant at 5\% (Table 4). The values of standard error of the estimate oscillated between $5.91 \%$ and $9.93 \%$, with emphasis to model 1 using the index LO. 
According to the " $\mathrm{F}_{\mathrm{ci}}$ " test, the competition indexes contributed statistically for the precision of projections, however in a lower intensity given by $\mathrm{S}_{\mathrm{yx}} \%$ and $\mathrm{R}_{\mathrm{aj}}{ }_{\mathrm{aj}}$, in relation to the equations of diameter projection. The index LO was an exception for model 4 with a similar result to the model for diameter projection.

Table 4. Coefficients and statistics of models used to project total height in a Pinus taeda stand in the Telêmaco Borba region, Paraná state, Brazil

Tabela 4. Coeficientes e estatísticas dos modelos empregados para projetar a altura total para povoamento de Pinus taeda localizado na região de Telêmaco Borba, Paraná, Brasil

\begin{tabular}{|c|c|c|c|c|c|c|c|c|c|c|}
\hline $\mathrm{N}^{0}$. & Model & $\beta_{0}$ & $\beta_{1}$ & $\boldsymbol{\beta}_{2}$ & $\beta_{3}$ & $\beta_{4}$ & $\beta_{5}$ & $\mathbf{R}^{2}{ }_{\text {aj }}$ & $\mathbf{S}_{\mathbf{y x}} \%$ & $\mathbf{F}_{\mathbf{c i}}$ \\
\hline \multirow{3}{*}{1} & W/out IC & $1.2524 *$ & $0.7723 *$ & $0.2739 *$ & $0.0439 *$ & $-0.0033 *$ & - & 0.96 & 6.70 & - \\
\hline & ST & $-0.3142^{*}$ & $0.5433^{*}$ & $0.5242 *$ & $0.0954 *$ & $0.0370^{*}$ & $-0.6188^{*}$ & 0.97 & 6.25 & $12,542.5^{*}$ \\
\hline & LO & $1.1139 *$ & $0.3231 *$ & $0.6614^{*}$ & $0.1468^{*}$ & $0.0517 *$ & $-0.0322 *$ & 0.97 & 5.91 & $24,214.7 *$ \\
\hline \multirow{3}{*}{2} & W/out IC & $13.3480 *$ & $0.0224 *$ & $-980.917 *$ & $0.4384 *$ & - & - & 0.96 & 7.03 & - \\
\hline & ST & $12.8898^{*}$ & $0.0215^{*}$ & $-1089.27^{*}$ & $0.9305^{*}$ & $-0.4680^{*}$ & - & 0.96 & 6.64 & $10,324.6^{*}$ \\
\hline & LO & $14.7394 *$ & $0.0197 *$ & $-1057.01 *$ & $0.9423 *$ & $-0.0256^{*}$ & - & 0.97 & 5.99 & $31,889.4^{*}$ \\
\hline \multirow{3}{*}{3} & W/out IC & $1.33958 *$ & $-80.985^{*}$ & $0.2767 *$ & - & - & - & 0.92 & 9.93 & - \\
\hline & ST & $0.97039 *$ & $-65.024 *$ & $0.3452 *$ & $-0.0604 *$ & - & - & 0.93 & 9.02 & $36,719.1 *$ \\
\hline & LO & $0.76823 *$ & $-33.453 *$ & $0.3468 *$ & $-0.0032 *$ & - & - & 0.95 & 7.70 & $91,539.0^{*}$ \\
\hline \multirow{3}{*}{4} & W/out IC & $1.06252 *$ & $0.6115^{*}$ & $-0.2913 *$ & $-0.0612 *$ & - & - & 0.96 & 6.77 & - \\
\hline & ST & $-0.2519^{*}$ & $0.4783 *$ & $-0.4009^{*}$ & $0.0141^{*}$ & $-0.0906^{*}$ & - & 0.96 & 6.49 & $24,109.7 *$ \\
\hline & LO & $-0.7211^{*}$ & $0.2034 *$ & $-0.5275^{*}$ & $0.1022 *$ & $-0.2558^{*}$ & - & 0.97 & 6.12 & $-1,134.7^{\mathrm{ns}}$ \\
\hline \multirow{3}{*}{5} & W/out IC & $-1.2119^{*}$ & $-0.4235^{*}$ & $0.1997 *$ & - & - & - & 0.94 & 8.46 & - \\
\hline & ST & $0.0288 *$ & $-0.3467 *$ & $0.2737 *$ & $-0.1293 *$ & - & - & 0.95 & 7.80 & $30,663.1^{*}$ \\
\hline & LO & $-0.9446^{*}$ & $-0.2628 *$ & $0.2729 *$ & $-0.2613^{*}$ & - & - & 0.96 & 6.91 & $26,474.2 *$ \\
\hline
\end{tabular}

Where: W/out IC = fitted model without the competition index; ST = competition index (Stage - BAL); LO = competition index (Lorimer); $\mathrm{R}^{2}{ }_{\mathrm{aj}}=$ adjusted coefficient of determination; $\mathrm{S}_{\mathrm{yx}} \%=$ standard error of the estimate percentage; $\mathrm{F}_{\mathrm{ci}}=\mathrm{F}$-test for the increment or marginal contribution; $\beta_{\mathrm{i}}=$ estimated coefficients; $*$ significant at $5 \% ;{ }^{\text {ns }}=$ non-significant at $5 \%$.

The boxplots of residuals for the model 1 of total height projection using the competition index LO is shown in Figure 2. These boxplots indicate that the range of variation around $\pm 25 \%$, except for the class of $5 \mathrm{~m}$, around $\pm 30 \%$. Disregarding the extreme values, an increase of precision of projected values in the class of $9 \mathrm{~m}$ was observed.

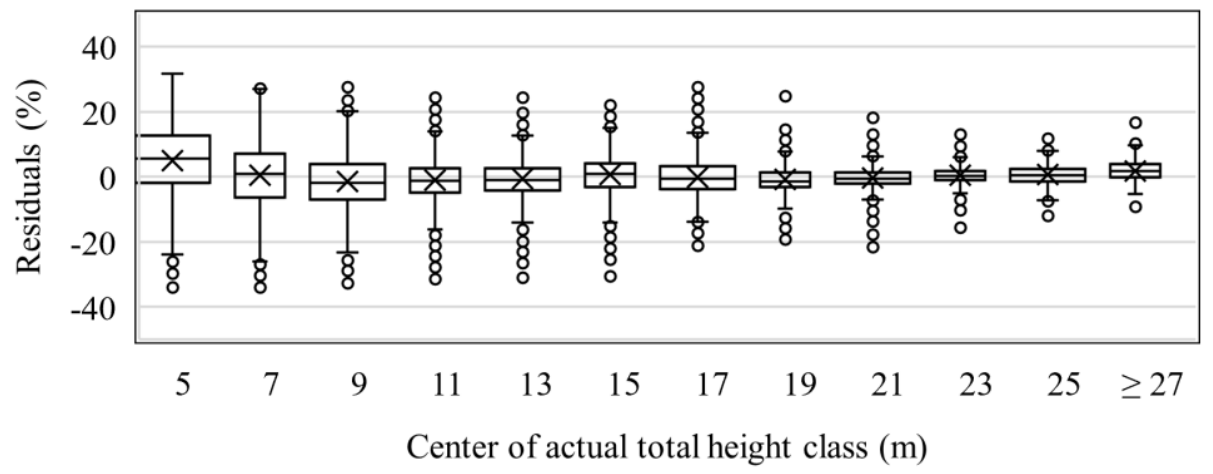

Figure 2. Boxplots of residuals by class of actual total height for model 1, with competition index LO for projection of total height in a Pinus taeda stand in the Telêmaco Borba region, Paraná state, Brazil.

Figura 2. Boxplots dos resíduos por classe de altura total atual para o modelo 1, com índice de competição LO, para projeção da altura total em povoamento de Pinus taeda localizado na região de Telêmaco Borba, Paraná, Brasil.

\section{Testing of the diameter and height projection models}

The model 1 was chosen as the most suitable for projection of diameter and total height, in the first case using the GH index, in the second using the LO index. These models were applied to the selected data for testing the estimated parameters. For the projection model of diameter (model 1) with the index GH, the RMSD was 
$5.50 \%$. For the projection model of total height (model 1) using the index LO, the same statistics was 5,98\%. The boxplots of residuals for both models are shown in Figure 3.

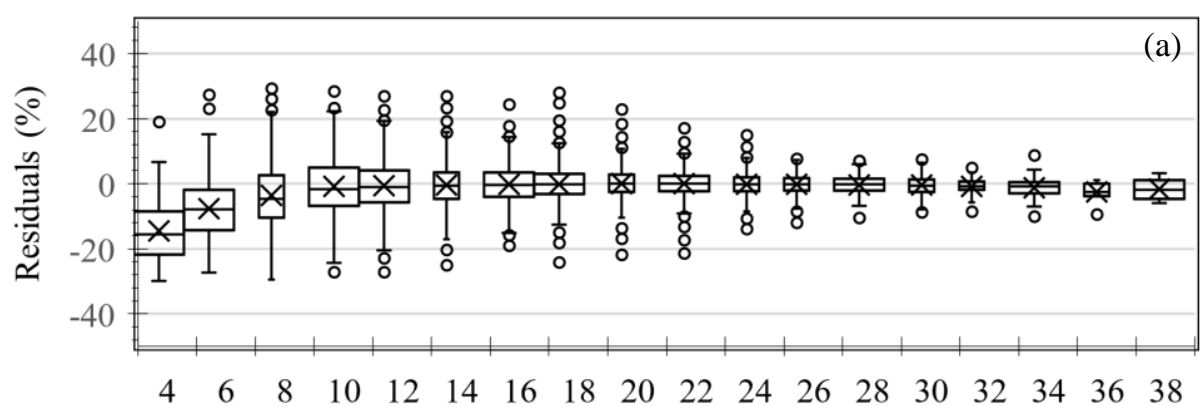

Center of actual diameter class $(\mathrm{cm})$

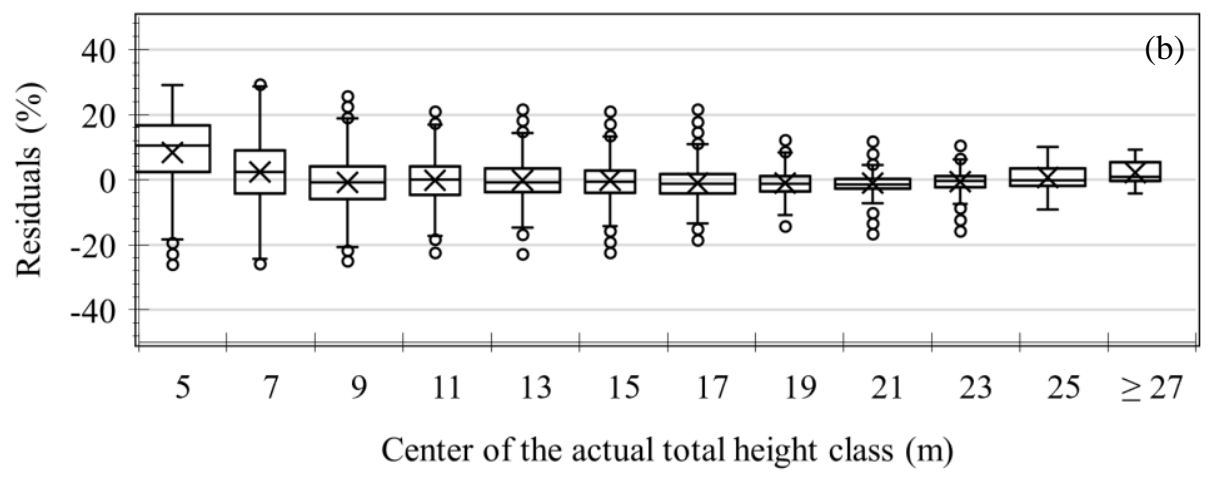

Figure 3. Boxplots of residuals by current diameter class in the projection models of diameter (a) and current total height class in the projection models of total height (b) to the selected data for testing, in a Pinus taeda stand in the Telêmaco Borba region, Paraná state, Brazil.

Figura 3. Boxplots dos resíduos por classe de diâmetro atual dos modelos para projeção do diâmetro (a) e por classe de altura total atual dos modelos para projeção da altura total (b) aos dados separados para teste, em povoamento de Pinus taeda localizado na região de Telêmaco Borba, Paraná, Brasil.

The projections by model 1 for the variable diameter (a) and total height (b) are shown in Figure 4, for the site index classes I $(30.5 \mathrm{~m})$, II $(25.5 \mathrm{~m})$, and III $(20.5 \mathrm{~m})$. For this projection, mean values of basal area $\left(\mathrm{m}^{2} \mathrm{ha}^{-1}\right)$ by age and site classes were considered.
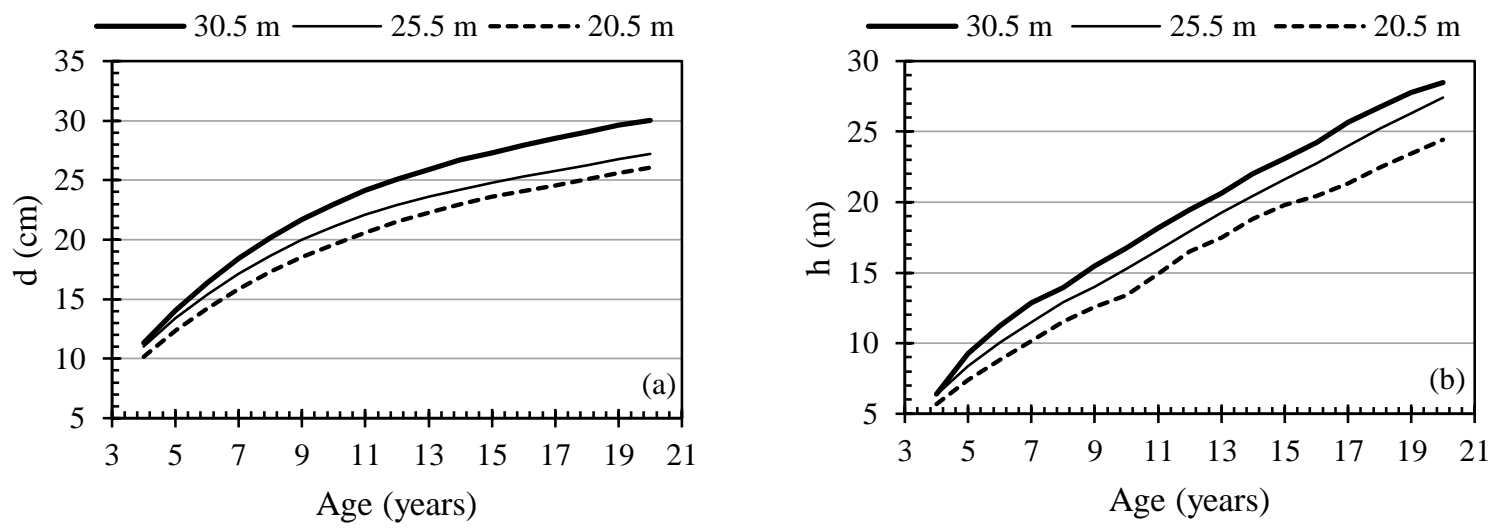

Figure 4. Diameter (a) and total height (b) projection according to site classes $30.5,25.5$ and 20.5 m, by model 1, in a Pinus taeda stand in the Telêmaco Borba region, Paraná state, Brazil.

Figura 4. Projeção do diâmetro (a) e da altura total (b) em função das classes de sítio, a partir do modelo 1, em povoamento de Pinus taeda localizado na região de Telêmaco Borba, Paraná, Brasil. 


\section{DISCUSSION}

Despite the result of t-test, improvements in quality and precision were to a minimum mainly for models 1 and 4. In these cases, it is likely that one or other model would provide similar results. It can be a reflex of the high correlation between the competition indexes and the diameter measured in the current age, since these indexes are obtained according to this variable.

The verification of the contribution of competition indexes in predictive models using the $\mathrm{F}$ test was performed by other studies. As an example, Tomé and Burkhart (1989) for E. globulus in Portugal; Martins et al. (2011) for clonal eucalyptus plantations in Monte Dourado, state of Pará, Brazil.

As observed in this work, the GH competition index was highlighted in other studies. Santos et al. (2015) observed a high correlation of the GH index with the the increment in transversal area for imbuia $(O$. porosa) in Rio Negro, Paraná, Brazil. Aakala et al. (2013) observed that the GH index was the one that best estimated growth for Pinus resinosa in North Minnesota, United States.

Vieira et al. (2018) observed that the GH index was the one that most correlated with the diameter and height growth and age, in clonal eucalyptus plantations. This index was strongly recommended to determine competition between homogenous stands of the same age, size and potential growth (DIMOV et al., 2008).

These results show the importance of using competition indexes to model individual trees, what indicates that a variable expressing the competitive status significantly contributes to the prediction of dimensional variables of trees. Independent variables that express competitive status, in addition to tree size and stand attributes are used in modelling of tree growth (WYKOFF, 1990).

Tomé and Burkhart (1989) and Wykoff (1990) used a multiple linear model to estimate growth in diameter and transversal area for individual trees. Estimates were established according to the variables related to tree size, competitive status, and the productive capacity of a location.

The slight tendency to overestimate the diameters in the initial classes is not a major problem. This is because these diameters are found in young ages, under five years, which are generally not used as a starting point for projections for the genus Pinus, because forest inventories usually start after that age.

As in the equation to project diameter, the observations made regarding the " $F_{c i}$ " test are suitable for the equation of height projection, whose p-values have also assumed values of zero or nearly zero. Martins et al. (2011) observed that indexes contributed statistically to the increment models for height in clonal stands of eucalyptus, in Monte Dourado, Pará, Brazil.

The LO competition index contributed to obtain better estimates of total height. Other works have also used the Lorimer index to assess the increment of dendrometric variables. Fraver et al. (2014) used the index of Hegyi and the modified index of Lorimer (LO) to assess the factors that affect the competitive environment of trees of Norway spruce (Picea abies (L.) Karst.) from the Swedish boreal forest.

The competition between trees clearly affected the growth rate, being the crown volume the variable that most contributed for competition. Schons et al. (2020) highlighted the competition index of LO in the correlation between the competition indexes and the periodic increment in transversal area for some species of the Mixed Ombrophylous Forest, in the National Forest of Irati, Paraná state, Brazil.

The diameter and height projection models showed non-constant variance in the different diameter classes, which possibly can be solved by using models that consider heteroscedasticity, as generalized linear models. This result may reflect the non-linear effect of competition indexes, which did not show a clear trend of increase or decrease, especially for larger trees and in less productive sites.

When applying the selected models to the data selected for testing, statistics remained similar to those obtained with the fitting data.

The range of residuals for the model of diameter projection was very similar to that from the fitting data (Figure 3a), being the same behaviour observed for the model of total height projection, with a slight inferiority of precision of projections, given the higher residual range (Figure 3b). For both models, a higher precision was observed for bigger trees, with a substantial part of boxplots indicating symmetry in residuals distribution, a desirable property in models of linear regression (GUJARATI; PORTER, 2011). Smaller precisions were verified in smaller trees for both diameter and total height, inferring to this observation the reflex of data variability, especially in early ages.

For both variables, projections were capable to differentiate the growth pattern according to the characteristic of the location, where higher productions are observed in more productive sites (Figure 4). Diameter projections indicated a higher inclination with tendency to reach the asymptotic value in previous ages regarding total height (Figure 4a). The projections of total height provided increasing values to a higher rate than diameter, the same tendency of observed values (Figure $4 b$ ).

The use of competition indexes in individual modelling of trees for diameter and height projection were significant, resulting in better estimates, assuming as true the hypothesis of this study. The importance of 
competition indexes in prediction models was highlighted by Reyes-Muñoz et al. (2011) for a mixed forest of Pinus sp. and Quercus sp. in Mexico.

\section{CONCLUSIONS}

- The models for diameter and total height provided precise projections, according to the variable itself in the current age, as well as the projection age, basal area in the current age, and site index.

- The competition indexes incorporated to projection models have significant contribution to project diameter and total height of Pinus taeda, with emphasis to the indexes of Glover and Hool (GH) and Lorimer (LO), respectively.

\section{REFERENCES}

AAKALA, T.; FRAVER, S.; D’AMATO, A. W.; PALIK, B. J. Influence of competition and age on tree growth in structurally complex old-growth forests in northern Minnesota, USA. Forest Ecology and Management, Amsterdam, v.308, p.128-135, 2013. Disponível em: http://dx.doi.org/10.1016/j.foreco.2013.07.057

BURKHART, H. E.; TOMÉ, M. Modeling forest trees and stands. New York: Springer, 457p. 2012. Disponível em: http://dx.doi.org/10.1007/978-90-481-3170-9

CARRIJO, J. V. N.; FERREIRA, A. B. F.; FERREIRA, M. C.; AGUIAR, M. C.; MIGUEL, E. P.; MATRICARDI, E. A. T.; REZENDE, A. V. The growth and production modeling of individual trees of Eucalyptus urophylla plantations. Journal of Forestry Research, v.31, p.1663-1672, 2019. Disponível em: https://doi.org/10.1007/s11676-019-00920-1

CASTRO, R. V. O.; SOARES, C. P. B.; LEITE, H. G.; SOUZA, A. L.; MARTINS, F. B.; NOGUEIRA, G. S.; OLIVEIRA, M. L. R.; SILVA, F. S. Competição em nível de árvore individual em uma Floresta Estacional Semidecidual. Silva Lusitana, Lisboa, v.22, n.1, p.43-66, 2014.

CHASSOT, T.; FLEIG, F. D.; FINGER, C. A. G.; LONGUI, S. J. Modelos de crescimento em diâmetro de árvores individuais de Araucaria angustifolia (Bertol.) Kuntze em Floresta Ombrófila Mista. Ciência Florestal, Santa Maria, v.21, n.2, 2011, p.303-313. Disponível em: https://doi.org/10.5902/198050983234

CLIMATE-DATA.ORG., 2020. Climate data for world cities. Available in: https://pt.climate-data.org/americado-sul/brasil/parana/telemaco-borba-765176/. Accessed on: Fev 17, 2021.

CONTRERAS, M. A.; AFFLECK, D.; CHUNG, W. Evaluating tree competition indices as predictors of basal area increment in western Montana forests. Forest Ecology and Management, Amsterdam, v.262, n.11, p.1.9391.949, 2011. Disponível em: http://dx.doi.org/10.1016/j.foreco.2011.08.031

COSTA, E. A.; FINGER, C. A. G.; SCHNEIDER, P. R.; HESS, A. F.; LIESENBERG, V.; SCHONS, C. T. Modelado de índices de competencia para Araucaria angustifolia en dos sitios en el sur de Brasil. Bosque, Valdivia, v.41, n.1, p.65-75, 2020. Disponível em: http://dx.doi.org/10.4067/S0717-92002020000100065

CUNHA, T. A. FINGER, C. A. G.; HASENAUER, H. Tree basal area increment models for Cedrela, Amburana, Copaifera and Swietenia growing in the Amazon rain forests. Forest Ecology and Management, Amsterdam, v.365, n.1, p.174-183, 2016. Disponível em: https://doi.org/10.1016/j.foreco.2015.12.031

DIMOV, L. D.; CHAMBERS, J. L.; LOCKHART, B. R. Five-year radial growth of red oaks in mixed bottomland hardwood stands. Forest Ecology and Management, Amsterdam, v.255, n.7, p.2.790-2.800, 2008. Disponível em: http://dx.doi.org/10.1016/j.foreco.2008.01.070

FRAVER, S.; D’AMATO, A. W.; BRADFORD, J. B.; JONSSON, B. G.; JÖNSSON, M.; ESSEEN, P. A. Tree growth and competition in an old-growth Picea abies forest of boreal Sweden: influence of tree spatial patterning. Journal of Vegetation Science, Knivsta, v.25, n.2, p.374-385, 2014. Disponível em: http://dx.doi.org/10.1111/ jvs. 12096

GUJARATI, D. N.; PORTER, D. C. Econometria Básica. Porto Alegre: McGraw-Hill Bookman, 5a ed., 2011. 924p.

MACHADO, S. A.; ACCIOLY, Y., NASCIMENTO, R. G. M.; SILVA, L. C. R.; CARDOZO, C. C. Influência do comprimento de copa na relação hipsométrica de Araucaria angustifolia. Pesquisa Florestal Brasileira, Colombo, v.35, n.83, p.343-351, 2015. Disponível em: https://doi.org/10.4336/2015.pfb.35.83.493 
MARTINS, F. B.; SOARES, C. P. B.; LEITE, H. G.; SOUZA, A. L.; CASTRO, R. V. O. Índices de competição em árvores individuais de eucalipto. Pesquisa Agropecuária Brasileira, Brasília, v.46, n.9, p.1.089-1.098, 2011. Disponível em: http://dx.doi.org/10.1590/S0100-204X2011000900017

ORELLANA, H.; FIGUEIREDO FILHO, A.; PÉLLICO NETTO, S.; VANCLAY, J. K. A distance-independent individual-tree growth model to simulate management regimes in native Araucaria forests. Journal of Forest Research, v.22, n.1, p.30-35, 2016. Disponível em: https://doi.org/10.1080/13416979.2016.1258961

PEDERSEN, R. O.; NAESSET, E.; GOBAKKEN, T.; BOLLANDAS, O. M. On the evaluation of competition indices-The problem of overlapping samples. Forest Ecology and Management, Amsterdam, v.310, p.120-133, 2013. Disponível em: https://doi.org/10.1016/j.foreco.2013.07.040

REYES-MUÑOZ, J. L.; AGUIRRE-CALDERÓN, O. A.; JIMÉNEZ-PÉREZ, J.; TREVIÑO-GARZA, E. J.; JURADO, E.; GONZÁLEZ-LAREDO, R. F. Modelos de predicción del incremento en volumen para bosques mezclados del Estado de Durango, México. Chapingo. Serie Ciencias Forestales y del Ambiente, Chapingo, v.17, n.1, p.103-113, 2011. Disponível em: https://dx.doi.org/10.5154/r.rchscfa.2010.05.026

SANQUETTA, C. R., SANQUETTA, M. N. I., BASTOS, A., QUEIROZ, A.; CORTE. A. P. D. Estimativa da altura e do volume em povoamentos jovens de restauração florestal em Rondônia. BIOFIX Scientific Journal, Curitiba, v. 2, n. 2, p. 23-31, 2017. Disponível em: http://dx.doi.org/10.5380/biofix.v2i2.54124

SANTOS, A. T.; MATTOS, P. P.; BRAZ, E. M.; ROSOT, N. C. Determinação da época de desbaste pela análise dendrocronológica e morfométrica de Ocotea porosa (nees \& mart.) barroso em povoamento não manejado. Ciência Florestal, Santa Maria, v.25, n.3, p.699-709, 2015. Disponível em: http://dx.doi.org/10.5902/1980509819620

SCHONS, C. T.; FIGUEIREDO FILHO, A.; SANTOS, T. L.; NASCIMENTO, R. G. M. Índices de competição em nível de árvore individual para espécies da Floresta Ombrófila Mista. Scientia Forestalis, Piracicaba, v.48, n.128, p.e3275, 2020. Disponível em: https://doi.org/10.18671/scifor.v48n128.13

SILVEIRA, B. D.; FLORIANO, E. P.; NAKAJIMA, N. Y.; HOSOKAWA, R. T.; ROSOT, N. C.; GRACIOLI, C. R. Relação da morfometria e competição com o crescimento de Trichilia claussenii em um fragmento de floresta Semidecidual, RS. Floresta, Curitiba, v.45, n.2, p.373-382, 2015. Disponível em: http://dx.doi.org/10.5380/rf.v45i2.35164

TOMÉ, M.; BURKHART, H. E. Distance-dependent competition measures for predicting growth of individual tree. Forest Science, v.35, n.3, p.816-831, 1989. Disponível em: https://doi.org/10.1093/forestscience/35.3.816

VIEIRA, G. C.; MENDONÇA, A. R.; SILVA, G. F.; ZANETTI, S. S.; SILVA, M. M.; SANTOS, A. R. Prognoses of diameter and height of trees of eucalyptus using artificial intelligence. Science of The Total Environment, Amsterdam, v.619-620, p.1.473-1.481, 2018. Disponível em: http://dx.doi.org/10.1016/j.scitotenv.2017.11.138

WEISKITTEL, A. R.; HANN, D. W.; KERSHAW, J. A. J; VANCLAY, J. K. Forest Growth and Yield Modeling. Oxford: John Wiley \& Sons, 415p. 2011. Disponível em: http://dx.doi.org/10.1002/9781119998518

WYKOFF, W. R. A basal area increment model for individual conifers in northern Rocky Mountains. Forest Science, v.36, n.4, p.1.077-1.104, 1990. Disponível em: https://doi.org/10.1093/forestscience/36.4.1077 